\title{
A factor analysis approach to modelling the early diversification of terrestrial vegetation
}

\author{
E. Capel ${ }^{1}$, C.J. Cleal ${ }^{2}$, P. Gerrienne ${ }^{3 \dagger}$, T. Servais ${ }^{4}$, B. Cascales-Miñana ${ }^{4 *}$
}

${ }^{1}$ Univ. Lille, CNRS, UMR 8198 - Evo-Eco-Paleo, F-59000 Lille, France (eliott.capel@ univlille.fr)

${ }^{2}$ Department of Natural Sciences, National Museum Wales, Cardiff CF10 3NP, UK

(chris.cleal@museumwales.ac.uk)

${ }^{3}$ EDDy lab/Palaeobotany and Palaeopalynology, Univ. Liege, 4000 Liege, Belgium

${ }^{4}$ CNRS, Univ. Lille, UMR 8198 - Evo-Eco-Paleo, F-59000 Lille, France

(thomas.servais@univ-lille.fr, borja.cascales-minana@univ-lille.fr)

*Corresponding author

†Deceased 


\begin{abstract}
Data from a new comprehensive macrofossil-based compilation of early plant genera are analyzed via a Q-mode factor analysis. This compilation ranges from the Silurian to the earliest Carboniferous and illustrates the key vegetation changes that took place during the configuration of early terrestrial ecosystems. Results reveal that four factors can be used to explain more than $90 \%$ of the variance in the data. These factors are interpreted as the major phases of the early land plant evolution: a first Eotracheophytic flora (Silurian-Lochkovian) dominated by basal eutracheophytes and rhyniophytoids, an early Eophytic Flora (Early Devonian) dominated by zosterophylls, a transitional late Eophytic Flora (Middle Devonianearliest Carboniferous) dominated by lycopsids and cladoxylopsids, and finally, the earliest phase of the Palaeophytic Flora (Late Devonian-earliest Carboniferous) dominated by the first seed plants. These floras present different but complementary diversity patterns, which help us to understand the overall trajectory of changes in plant diversity. Results further show how the maximum peaks of diversity appear linked to the rise of each new flora but, interestingly, these diversifications are not associated with any exponential declines of the previously dominant one. This new four-phase diversification model reflects the early steps of Earth's greening.
\end{abstract}

Keywords: Devonian, Early land plants, Factor analysis, Plant macrofossil, Plant radiation, Terrestrialization. 


\section{Introduction}

The terrestrialization of plants (embryophytes; Janvier, 2010; Gerrienne et al., 2016; Servais et al., 2019) during Ordovician-Devonian times altered early land ecosystems, instigating the development of soils, and causing major $p \mathrm{CO}_{2}$ fluctuations and changes in geochemical cycles (Algeo and Scheckler, 1998; Beerling, 2007; Kenrick et al., 2012; Morris et al., 2015; Xue et al., 2015, 2016; Qie et al., 2019). These changes were triggered by key diversification events among plants linked to the appearance of evolutionary innovations, such as vascular tissues, leaves, seeds and secondary growth (i.e., wood), which together culminated in the establishing of the earliest forests (Decombeix et al., 2011; Kenrick et al., 2012; Xue et al., 2015, 2016, 2018; Cascales-Miñana et al., 2019a; Wang et al., 2019; Stein et al., 2020). Since the 1980s, various researchers have focused their attention on documenting the diversity pattern of this early vegetation (e.g., Banks, 1980; Knoll et al., 1984; Edwards and Davies, 1990; Raymond and Metz, 1995; Meyer-Berthaud et al., 2010; Stein et al., 2012; Cascales-Miñana, 2016; Xue et al., 2016; Wang et al., 2019). This pattern, essential to understand the development of the early land biosphere, is characterized by a series of key diversity fluctuations. Such fluctuations range from the Ordovician-Silurian appearance of small plants, such as rhyniophytoids (many of them putative vascular plants, i.e., tracheophytes; Steemans et al., 2012; Gerrienne et al., 2016; Salamon et al., 2018), the earliest zosterophylls and lycopsids (Gensel and Berry, 2001; Kotyk et al., 2002), to the Early Devonian (Pragian) explosion of early leafy plants (i.e., euphyllophytes; Tomescu, 2009; Hao and Xue, 2013; Bickner and Tomescu, 2019), followed by the rise of the first forests and early seed plants in the Middle and Late Devonian, respectively (Decombeix et al., 2011; Xue et al., 2015, 2016; Stein et al., 2020). However, since many evolutionary innovations occurred during this time, the documentation of the early dynamics of plant diversity remains controversial.

The global trajectory of Phanerozoic vegetation history can be interpreted as a series of major evolutionary phases; the so-called Evolutionary Floras (see Cleal and Cascales-Miñana, 2014, and references therein for details). This model, which confirmed the major floral subdivisions previously suggested by Gothan (1912; see also Niklas et al., 1983, 1985; Edwards and Selden, 1992; Gray, 1993), is homologous to the famous Sepkoski's (1981) Evolutionary Faunas (Cascales-Miñana et al., 2018, fig. 1). Importantly, the Cleal and Cascales-Miñana's (2014) Evolutionary Floras reveal that Silurian-Devonian land plant diversification is expressed as at least three different great floras, termed Eotracheophytic, Eophytic and Palaeophytic (Servais et al., 2019, fig. 1B). This suggests that, beyond the known problems of sampling and geological 
bias that of course obscure raw diversity patterns, there is an underlying structure in the observed diversity data of early floras, which deserves further investigation. This is the aim of the present paper.

\section{Data}

This study is based on a new, comprehensive macrofossil-based compilation of Silurianlowermost Carboniferous (Tournaisian) fossil-genera. Raw data were collected from a variety of sources. Initially, we used review papers that listed plant fossil diversity for specific time intervals, such as Wellman et al. (2013) for the Silurian, or a specific geographic location, such as Xiong et al. (2013), or more recently Xue et al. (2018), for South China. Special mention should be made of the exquisite monographic study of the Early Devonian fossil record by Barrett (2016). Subsequently, plant fossil data were extracted from the Paleobiology Database via Fossilworks (http://fossilworks.org/) which were cross-checked against the primary references and, when possible, more recent literature. Lastly, numerous taxa were added from the primary literature, particularly recently described genera such as Lilingostrobus, Rinistachya, Kossoviella, Guangdedendron, Qianshouia or Keraphyton (Gerrienne et al., 2018; Prestianni and Gess, 2018; Orlova et al. 2019; Wang et al., 2019; Huang et al., 2020; Champreux et al., 2020).

To assess the maximum genus-level diversity, three types of data were considered. First, well-defined genera were listed that contained well-defined species (e.g., Cooksonia pertoni), and certain species in open nomenclature (e.g., Cooksonia cf. pertoni). Secondly, genera recorded with a 'cf.' were listed to bring together all species resembling such genera (e.g., cf. Cooksonia hemisphaerica). Lastly, genera recorded with an 'aff.' were listed to include taxa that have an affinity to that genus but whose assignment is still ambiguous (e.g., aff. Zosterophyllum). Overall, "artificial” genera (e.g., Taeniocrada) or synonyms of other taxa already listed were omitted. Likewise, some entries were also filtered to minimize an overlap of fossil-taxa for different plant parts (e.g., Callixylon/Archaeopteris or Calamophyton/Duisbergia; Meyer-Berthaud et al., 2000; Giesen and Berry, 2013) or different phases of life cycle (e.g., gametophytes). In total, more than 500 plant macrofossil genera were included, which provides a robust view of the major changes that took place during land plant diversification (Fig. 1).

The raw dataset was codified at stage and sub-stage level according to the literature and following the International Chronostratigraphic Chart 2019 (Cohen et al., 2013, updated). 
Twenty-five time units with an average resolution of 3.4 Myr were used. Each entry included the name and systematic affinity of the genus, its first and last stratigraphic occurrences, and the sampled localities on which the data were based. Raw data are available in Tables S1-S2. See also Text $\mathrm{S} 1$ for full referencing.

\section{Methods}

\subsection{Factor analysis}

We ran a CABFAC version of the Q-mode factor analysis on a data matrix containing the number of plant macrofossil genera occurring in each stratigraphic interval, grouped according to suprageneric taxonomic categories as defined below. The analysis was made using the PAST software package version 2.17 (Hammer et al., 2001). This method, widely used to analyse many different fossil-based datasets (e.g., Bottjer and Jablonski, 1988; Erwin, 1990; Sallan and Coates, 2010; Figueirido et al., 2012; Cleal and Cascales-Miñana, 2014), recognises different factors (orthogonal eigenvectors), each of which has associated eigenvalues (factor loadings) for each stratigraphical interval and the percentage of the total variance explained by that factor. Each factor also has a factor score for each plant group, which reflects the importance of that group on the factor. Following standard procedures, factor results were then rotated with a procedure known as Kaiser's (1958) Varimax rotation. The purpose of the rotation is to enhance the discrimination of the variables into the resulting factors, which will therefore represent more accurately the distinct associations of plant groups by reducing the influence of plant groups that are not typically correlated with this association on raw data. Each factor ultimately represents a proportion of the total genus-level diversity curve of each suprageneric group (Sepkoski, 1981; Cleal and Cascales-Miñana, 2014). From this, we extracted the patterns of association among the main early plant groups that explain the whole diversity pattern of Silurian-Devonian fossil floras.

\subsection{Assignment of taxa to categories}

To implement the factor analysis, taxa must be assigned to categories. As in previous models (e.g., Sepkoski, 1981), taxa were firstly grouped in taxonomic classes (Fig. 1A). Subsequently, taxa whose class attribution was controversial or undetermined ( $25 \%$ of the dataset) were assigned to groups based on evolutionary and/or morphological criteria. The Rhyniopsida 
required special attention. Taxa traditionally assigned to this class currently cover many different plant lineages, including paratracheophytes (i.e., former Rhyniaceae; Gerrienne et al., 2006) and basal eutracheophytes (e.g., Cooksonia; Kenrick and Crane, 1997; Crane et al., 2004; Gerrienne et al., 2016). The group also includes rhyniophyte-like plants or rhyniophytoids (e.g., Uskiella or Electorotheca; Morris et al., 2018), i.e., plants similar to tracheophytes but lacking evidence of vascular tissue, or plants of unknown affinities (Steemans et al., 2012). Other categories used for data analysis include cryptophytes (i.e., basal embryophytes; Morris et al., 2018), protracheophytes (i.e., Aglaophyton/Teruelia; Kenrick and Crane, 1997; CascalesMiñana and Gerrienne, 2017; Cascales-Miñana et al., 2019a) and stenokoleales (Momont et al., 2016; Toledo et al., 2018). Incertae sedis taxa ( 16\% of dataset) were grouped into two categories given that many of these plants presented euphyllophyte affinities. Basal euphyllophytes (i.e., formerly trimerophytes; Tomescu, 2009; Gensel, 2018) were treated like a single group. In total, 18 categories integrating the whole taxonomic and morphological diversity of early land plants were used for the data analysis (see Table 1).

\section{Results}

Fig. 1A shows the distribution of genus-level diversity among the main classes of Silurian Devonian land plants. From this, we see that each class seems to have its own pattern of diversity change, although some similarities are noteworthy. For instance, major Early Devonian groups such as rhyniopsids and zosterophyllopsids show a diversification in the midEarly Devonian followed by a significant depletion at the Early-Middle Devonian boundary. We also see a second diversification in the Middle Devonian among the lycopsids, cladoxylopsids and progymnosperms (Fig. 1A). A Late Devonian diversification of seed plants coinciding with a sustained increase of lycopsids is also noted (Fig. 1A). In the SilurianDevonian fossil record, many taxa are class-level incertae sedis so Fig. 1A does not include all plant diversity. However, this seems to be not so critical given that the general pattern of diversification and decay of the well-defined classes captures most of the total pattern of plant taxonomic diversity (Fig. 1B). This pattern is characterized by a gradual increase from the Ludlow, a great diversification in the mid-Early Devonian, a sudden decrease in the EarlyMiddle Devonian transition, an important pulse of diversification in the late Middle Devonian, a moderate reduction of diversity in the earliest Late Devonian, and finally, a pronounced and sustained increase towards the Carboniferous (Fig. 1B). 
Sepkoski (1981) chose a solution of three factors that explained c. $91 \%$ of the variance of marine faunal diversity. This was based on a "scree test" (see Sepkoski, 1981, fig. 2 for details), where the eigenvalues represented by each successive factor are plotted logarithmically. If there is an abrupt break in the slope of the resulting line, this is used to indicate the number of factors that should be recognised. We applied a similar approach with our data (Fig. 2), but no break in the slope was observed. A similar result was obtained by Cleal and Cascales-Miñana (2014, fig. 3), who therefore used instead the Kaiser Rule, in which the number of factors is decided based on how many are needed to account for $90 \%$ of the total variance of data. In the present study, using this guideline, the first four generated factors were used as the basis of the model to explain the Silurian-Devonian plant diversity patterns (see Table 2). The robustness of the model is supported by the fact that each factor is taxonomically and stratigraphically coherent, with clear temporal trends (compare comments by Flessa and Imbrie, 1975 on a faunal model), and thus seems to be reflecting the overall trajectory of Silurian-Devonian vegetation history (see below). The factor analysis was implemented twice, with and without Incertae sedis taxa, and these produced indistinguishable results.

These four rotated factors are interpreted as reflecting the major evolutionary phases of the diversification of early terrestrial floras. The floral composition of each factor is summarized in Table 3. Figure 3 illustrates the loadings of each factor for the successive time intervals, from which the genus-level diversities represented by each factor/flora have been calculated. This was done for each stratigraphical interval by squaring each of its four loading values and multiplying them by the total diversity for that interval (Fig. 4). The resulting four-factor model of early land plant diversification (Figs. 3-4) may be summarized (in stratigraphic order) as follows.

Factor 3 (Silurian-earliest Devonian). This factor is dominated by basal eutracheophytes and rhyniophytoids, with other minor elements including basal lycopsids (Table 3). This factor represents the Eotracheophytic flora (the Rhyniophytic flora sensu Cleal and Cascales-Miñana, 2014), and is compared to the previously described "Rhyniophytic Phase" of plant evolution (Edwards and Selden, 1992) and Gray's (1993) “'Eotracheophytic Flora”. The Eotracheophytic flora reflects the initial pulse of plant diversity and the main growth of taxonomic richness from the mid-Silurian to the earliest Devonian, which reached its maximum during the midLochkovian (Fig. 4).

Factor 1 (Early Devonian). This factor is dominated by zosterophyllopsids and rhyniophytoids, with other minor elements including horneophytopsids and paratracheophytes (Table 3). Interestingly, this factor also sees the early phase of the development of 
euphyllophyte plants. This factor represents the early phases of Cleal and Cascales-Miñana's (2014) Eophytic flora. This flora reaches its maximum diversity peak at the end-Pragian and represents the main component of Early Devonian plant diversity. After reaching a second peak at the end of the early Devonian, this early Eophytic Flora undergoes a progressive decline until the Frasnian-Famennian boundary (Fig. 4).

Factor 2 (Middle Devonian-earliest Carboniferous). This factor is dominated by lycopsids and cladoxylopsids, together with a diverse range of other groups (Table 3). Significantly, the progymnosperms, sphenopsids and filicopsids appear in this flora. This factor corresponds to a late phase of the Eophytic flora. After an initial diversification towards the end-Early Devonian, this flora shows an explosive diversification during the Middle Devonian with a maximum diversity peak at the Givetian. These late Eophytic floras slowly decline during the Late Devonian (Fig. 4). An overall diversity peak in the late Famennian is also observed (Fig. 4).

Factor 4 (Late Devonian-earliest Carboniferous). This factor is clearly dominated by spermatopsids (Table 3), mainly early seed ferns such as Calamopityales and Lyginopteridales (Wang and Liu, 2015), together with several groups including lycopsids and filicopsids (Table 3). This factor corresponds to the earliest phase of Cleal and CascalesMiñana's (2014) Palaeophytic flora. This flora started an exponential diversification from the Frasnian/Famennian boundary (Fig 4) and rapidly became dominant during the Carboniferous (Servais et al., 2019, fig. 1B).

\section{Discussion}

Total diversity patterns of early land plants based on taxon counts are inevitably flawed due to inherent taphonomic and sampling biases introduced by the fossil record. For instance, the volume of terrestrial rock exposed is an acknowledged bias (see Kenrick et al., 2012). There are also facies biases, notably because the plant fossil record is almost entirely from lowland nearshore deposits, which largely excludes remains of plants from extra-basinal habitats (similar to the situation in Carboniferous floras - Thomas and Cleal, 2017). A particular concern is the effect of sampling on taxon counts: for example, there are very few non-marine strata available for collecting in the Silurian (e.g., Kenrick et al., 2012; Hao and Xue, 2013; Wellman et al., 2013). Nevertheless, our results have clearly revealed changing patterns, affecting distinct plant groups and intervals, which are more suggestive of a biological signal than of geological bias. This can be observed for instance in the Eotracheophytic-Eophytic turnover, where 
although total diversity is consistently increasing, Eotracheophytic diversity is progressively diminishing (Fig 4).

The Silurian-Devonian plant fossil record shows the highest known diversity and disparity of plant groups. This is simply because all known plant groups except flowering plants, both living and fossil, are represented (Gerrienne et al., 2016, fig 2; Cascales-Miñana et al., 2019a, fig. 3). Nevertheless, despite these great variations in form, the factor analysis has revealed a rather simple diversity pattern of floral changes. This pattern shows a clear succession of "major evolutionary steps", growing in complexity from simple, small, leafless herbaceous plants to highly developed woody seed-plants, including the tree habit. Without doubt, this diversification allowed plant life to colonize different and new terrestrial environments, to create an emerging greening of Earth's surface. This scenario is quite logical and is evident for instance from the growing size of Devonian plants (Xue et al., 2018, fig. 16). However, beyond statistically supporting this collective view, the factor analysis provides an objective way of measuring the "weight" of change between early floras and their composition. For instance, from this, we can see how the dominance of the late Eophytic flora, which included the earliest forest plants, occurred very rapidly before the end of the Middle Devonian.

Like in the Sepkoski (1981) model, one of most important aspects in the history of these early Evolutionary Floras is that their rise and subsequent decline seem to be closely related to the total pattern of apparent plant diversity. The changes in total taxonomic richness per time interval is shown in Fig. 4 by the uppermost bold curve. The stippled field below this curve represents the residual diversity not explained by the four-factor solution of the model. This residual part is overall quite uniform and small, only becoming slightly larger towards the end of the Devonian (probably as a response to greater "noise" in the factors with the lowest eigenvalues). The small size of this residual diversity suggests that the first four selected factors, and the Evolutionary Floras represented by them, provide a robust framework to explain the overall diversity pattern, as well as providing a first-order description of the composition changes of each flora during the Devonian.

The scaling of the four-factor model to total generic diversity suggests that each of the major evolutionary floras is associated with a specific phase of plant diversification (Fig. 4). From this, we see that after an initial and continuous Silurian-Lower Devonian diversification in the Eotracheophytic flora, followed by an early diversification of the Eophytic flora, several ascending diversity trends can be observed. The first, at the end-Pragian, was a result of the rise and developing dominance of the early Eophytic flora. The second one, in the Givetian, was clearly related to an "explosive" expansion of the late Eophytic flora. The last significant 
increase of diversity occurs in the late Famennian and is linked to the initial diversification of the Palaeophytic flora. So, it seems that each of the four floras had its own independent but complementary pattern of generic diversity, which combined to produce the total dynamics of Silurian-Devonian plant diversity. The pattern of growth and decline of the early evolutionary floras suggests ecological displacement as the main cause of each turnover, but there was no equilibrium phase or exponential decline as was observed in the marine Evolutionary Faunas model.

Evolutionary innovations and the consequential diversification of various plant groups have been postulated to be the cause of turnover between different floras. This is partially supported here, especially for the Early Devonian Eotracheophytic-Eophytic transition. The changing pattern of these first floras, consisting of basal eutracheophytes, rhyniophytopsids and zosterophylls (Table 3), can be comfortably related to the improvements in the waterconducting system of land plants (Kenrick and Crane, 1997; Kenrick et al., 2012; Gensel, 2018). Overall, it is hypothesized that the rise of each of these floras was probably linked to key evolutionary developments such as in the growth in complexity (i.e., optimization) of the architecture of vascular system (Strullu-Derrien et al., 2013; Decombeix et al., 2019). At this time, land plants were undertaking a massive adaptive radiation and almost every anatomicalphysiological aspect was rapidly evolving. This scenario would support the idea of an initial colonization of the earliest terrestrial environments linked to improvements in hydraulic efficiency (Wilson, 2013, 2016; Cascales-Miñana et al., 2019b; Decombeix et al., 2019).

In contrast, the extremely high morphological disparity observed in the Middle-Late Devonian Evolutionary Floras do not support a diversification pattern that was always driven by the appearance and/or improvements of key evolutionary innovations. For instance, this can be observed from the Famennian, where the increase of plant diversity was a response to the dynamics of more than one great flora (Fig. 5). On the other hand, the appearance of the late Eophytic flora, which involved the worldwide colonization of lowland areas by the archaeopteridalean progymnosperms and pseudosporochnales (Cladoxylopsida), saw the development of the earliest forested landscapes (Meyer-Berthaud et al., 1999; Stein et al., 2007; Meyer-Berthaud and Decombeix, 2007; Decombeix et al., 2011); and the earliest phase of the Palaeophytic flora, which represents a transitional stage characterized by open vegetation ecosystems, included the first seed plants, notably non-arborescent pteridosperms, colonizing disturbed habitats (Mintz et al., 2010; Prestianni and Gerrienne, 2010; Decombeix et al., 2011).

During the last decades, significant discoveries of Devonian plants have been made in South China (see e.g., Hao and Xue, 2013; Xue et al., 2018, and references therein). After analysing 
the Silurian-Devonian taxonomic diversity of this record, Xiong et al. (2013) observed several major fluctuations of genus-level plant diversity, one at the Pragian, another from the midGivetian to mid-Frasnian, and a last one in the late Famennian. These fluctuations are similar to the results reported herein (Fig. 4), and suggest a common worldwide pattern of plant diversification. Xue et al. (2018) also performed a similar study to Xiong et al. (2013), but using a more conservative approach by retaining well-defined taxa only. Significantly, the proportions of major plant groups over time in the South China Block shown by Xue et al. (2018, fig. 9) approximately reflect the dominant elements of the Evolutionary Floras, e.g., the transition from a zosterophyllopsid-dominated flora to a lycopsid-dominated flora (Table 3); this provides further support for a global pattern of subsequent diversification phases of early vegetation. In contrast, although diversity studies on South China plant fossils suggest a Givetian crisis similar in magnitude to the Frasnian-Famennian marine crisis (Xiong et al., 2013), we see no global crisis in the vegetation of the Middle Devonian (Fig. 1B). Rather, our model shows a sustained increase in plant taxonomic and morphological diversity at this time (Figs. 1A), triggered by the Eophytic diversification (Fig. 4). Likewise, our model suggests that the reduction in plant diversity at the beginning of the Late Devonian (Fig. 4) is linked to the start of the Eophytic-Palaeophytic transition that resulted in more complex forest ecosystems.

\section{Conclusions}

Results have shown that the largest part of the variation dynamics in generic richness within the main Silurian-Devonian plant groups can be explained through a four-phase diversification model. This model is based on (1) a first Eotracheophytic flora that dominates the Silurian fossil record but decays suddenly after the Lochkovian, (2) an early Eophytic Flora that dominates the Early Devonian showing a continuous increase until the Pragian, (3) a late Eophytic Flora that dominates from the Middle Devonian to the Carboniferous, and lastly, (4) a sustained increase of a Palaeophytic flora from the Frasnian/Famennian boundary. Each evolutionary flora appears to be associated with distinct phases of diversification of early terrestrial ecosystems. The Eotracheophytic flora is associated with the earliest radiation of vascular plants, while the Eophytic floras are associated with the expansion of zosterophyllopsids and of lycopsids, respectively, and the appearance of cladoxylopsids and progymnosperms, i.e., the earliest trees. Likewise, the Palaeophytic flora is linked to the earliest diversification of seed plants. Finally, the results show that the expansion of each new flora triggers the progressive decline of the previously dominant flora, which suggests ecological displacement. In this sense, 
the pattern of succession of the early Evolutionary floras reflects the transition from environments covered by herbaceous plants to an early forested planet.

\section{Acknowledgments}

The authors thank the Région Hauts-de-France, the Ministère de l'Enseignement Supérieur et de la Recherche (CPER Climibio), and the Doctoral School for Materials, Radiation and Environmental Sciences of the University of Lille (Ecole Doctorale SMRE) for financial support. This is also a contribution to National Museum Wales research programme NS25: Plant diversity through 450 million years of Earth history.

\section{References}

Algeo, T.J., Scheckler, S.E., 1998. Terrestrial-marine teleconnections in the Devonian: links between the evolution of land plants, weathering processes, and marine anoxic events. Phil. Trans. R. Soc. Lond. 353, 113-130.

Banks, H.P., 1980. Floral assemblages in the Siluro-Devonian. In: Dilcher, D.L., Taylor, T.N. (Eds.), Biostratigraphy of Fossil Plants: successional and Palaeoecological Analyses. Dowden, Hutchinson and Ross, Stroudsburg, Pennsylvania, USA, 1-24.

Barrett, J.A., 2016. Plant Diversity in the Early Devonian-Stratigraphic and Geographic Patterns. Humboldt State University, Arcata, 856 pp.

Beerling, D.J., 2007. The emerald planet: how plants changed Earth's history. Oxford University Press, Oxford, 288 pp.

Bickner, M.A., Tomescu, A.M., 2019. Structurally complex, yet anatomically plesiomorphic: permineralized plants from the Emsian of Gaspé (Québec, Canada) expand the diversity of Early Devonian euphyllophytes. IAWA J. 40, 421-445.

Bottjer, D.J., Jablonski, D., 1988. Paleoenvironmental patterns in the evolution of postPaleozoic benthic marine invertebrates. Palaios 3, 540-560.

Cascales-Miñana, B., 2016. Apparent changes in the Ordovician-Mississippian plant diversity. Rev. Palaeobot. Palynol. 227, 19-27.

Cascales-Miñana, B., Gerrienne, P., 2017. Teruelia diezii gen. et sp. nov.: an early polysporangiophyte from the Lower Devonian of the Iberian Peninsula. Palaeontology 60, 199-212. 
Cascales-Miñana, B., Servais, T., Cleal, C. J., Gerrienne, P., Anderson, J., 2018. Plants-the great survivors! Geol. Today 34, 224-229.

Cascales-Miñana, B., Steemans, P., Servais, T., Lepot, K., Gerrienne, P., 2019a. An alternative model for the earliest evolution of vascular plants. Lethaia 52, 445-453.

Cascales-Miñana, B., Gerrienne, P., Sirjacq, B., Steemans, P., 2019b. On the hydraulic conductance of three woody Devonian plants. IAWA J. 40, 446-465.

Champreux, A., Meyer-Berthaud, B., Decombeix, A., 2020. Keraphyton gen. nov., a new Late Devonian fern-like plant from Australia. PeerJ 8:e9321.

Cleal, C.J., Cascales-Miñana, B., 2014. Composition and dynamics of the great Phanerozoic Evolutionary Floras. Lethaia 47, 469-484.

Cohen, K.M., Finney, S.C., Gibbard, P.L., Fan, J.-X., 2013 (updated). The ICS International Chronostratigraphic Chart. Episodes 36, 199-204.

Crane, P.R., Herendeen, P., Friis, E.M., 2004. Fossils and plant phylogeny. Am. J. Bot. 91, $1683-1699$.

Decombeix, A.-L., Meyer-Berthaud, B., Galtier, J., 2011. Transitional changes in arborescent lignophytes at the Devonian-carboniferous boundary. J. Geol. Soc. Lond. 168, 547-557.

Decombeix, A.-L., Boura, A., Tomescu, A.M.F., 2019. Plant hydraulic architecture through time: lessons and questions on the evolution of vascular systems. IAWA J. 40, 387-420.

Edwards, D., Davies, M.S., 1990. Interpretations of early land plant radiations: 'facile adaptationist guesswork' or reasoned speculation? In: Taylor, P.D., Larwood, G.P. (Eds.), Major Evolutionary Radiations. Clarendon Press, Oxford, 351-376.

Edwards, D., Selden, P.A., 1992. The development of early terrestrial ecosystems. Bot. J. Scot. 46, 337-366.

Erwin, D.H., 1990. Carboniferous-Triassic gastropod diversity patterns and the Permo-Triassic mass extinction. Paleobiology 16, 187-203.

Figueirido, B., Janis, C.M., Pérez-Claros, J.A., De Renzi, M., Palmqvist, P., 2012. Cenozoic climate change influences mammalian evolutionary dynamics. Proc. Natl. Acad. Sci. USA. 109, 722-727.

Flessa, K.W. Imbrie, J., 1975. Evolutionary pulsations: evidence from Phanerozoic diversity patterns. In: Tarling, D.H., Runcorn, S.K. (Eds.), Implications of continental drift to the Earth sciences. Vol. 1. Academic Press, London, 247-285.

Frederiksen, N.O. 1972: The rise of the mesophytic flora. Geoscience and Man 4, 17-28. 
Gensel, P.G., 2018. Early Devonian Woody Plants and Implications for the Early Evolution of Vascular Cambia. In: Krings, M., Harper, C., Cuneo, R., Rothwell, G.W. (Eds.), Transformative Paleobotany. Academic Press, pp. 21-33.

Gensel, P.G., Berry, C.M., 2001. Early lycophyte evolution. Am. Fern J. 91, 74-98.

Gerrienne, P., Servais, T., Vecoli, M., 2016. Plant evolution and terrestrialization during Palaeozoic times-The phylogenetic context. Rev. Palaeobot. Palynol. 227, 4-18.

Gerrienne, P., Cascales-Miñana, B., Prestianni, C., Steemans, P., Cheng-Sen, L., 2018. Lilingostrobus chaloneri gen. et sp. nov., a Late Devonian woody lycopsid from Hunan, China. PLOS ONE, 13, e0198287.

Gerrienne, P., Dilcher, D.L., Bergamaschi, S., Milagres, I., Pereira, E., Rodrigues, M.A.C., 2006. An exceptional specimen of the early land plant Cooksonia paranensis, and a hypothesis on the life cycle of the earliest eutracheophytes. Review of Palaeobotany and Palynology 142, 123-130.

Giesen, P., Berry, C.M., 2013. Reconstruction and growth of the early tree Calamophyton (Pseudosporochnales, Cladoxylopsida) based on exceptionally complete specimens from Lindlar, Germany (Mid-Devonian): Organic Connection of Calamophyton branches and Duisbergia Trunks. Int. J. Plant Sci. 174, 665-686.

Gray, J., 1993. Major Paleozoic land plant evolutionary bioevents. Palaeogeogr. Palaeoclimatol. Palaeoecol. 104, 153-169.

Gothan, W., 1912. Paläbotanik. In: Korschelt, E., Linck, G., Schaum, K., Simon, H.T., Verworn, M., Teichmann, W. (Eds.), Handwörterbuch der Naturwissenschaften. Fischer, Jena, pp. 408-460.

Hammer, Ø., Harper, D.A.T., Ryan, P.D., 2001. PAST: Paleontological Statistics software package for education and data analysis. Palaeontol. Electron. 4, 1-9.

Hao, S.G., Xue, J.Z., 2013. The Early Devonian Posongchong Flora of Yunnan. Science Press, Beijing, 366pp.

Huang, P., Liu, L., Liu, L., Qin, M., Wang, D.M., Xue, J.X., 2020. A new plant with novel leaves from the Upper Devonian of Zhejiang Province, China. Palaeoworld, In Press.

Janvier, P., 2010. Terrestrialization: The early emergence of the concept. Geol. Soc. Lond. Spec. Publ. 339, 5-9.

Kaiser, H.F., 1958. The varimax criterion for analytic rotation in factor analysis. Psychometrika 23, 187-200.

Kenrick, P., Crane, P.R., 1997. The origin and early evolution of plants on land. Nature 389, 33-39. 
Kenrick, P., Wellman, C.H., Schneider, H., Edgecombe, G.D., 2012. A timeline for terrestrialization: consequences for the carbon cycle in the Palaeozoic. Philos. Trans. R. Soc. B. $367,519-536$.

Knoll, A.H., Niklas, K.J., Gensel, P.G., Tiffney, B.H., 1984. Character diversification and patterns of evolution in early vascular plants. Paleobiology 10, 34-47.

Kotyk, M.E., Basinger, J.F., Gensel, P.G., De Freitas, T.A., 2002. Morphologically complex plant macrofossils from the Late Silurian of Arctic Canada. Am. J. Bot. 89, 1004-1013.

Meyer-Berthaud, B., Schuckler, S.E., Wendt, J., 1999. Archaeopteris is the earliest known modern tree. Nature 398, 700-701.

Meyer-Berthaud, B., Decombeix, A.L., 2007. A tree without leaves. Nature 446, 861-862.

Meyer-Berthaud, B., Scheckler, S.E., Bousquet, J.L., 2000. The development of Archaeopteris: new evolutionary characters from the structural analysis of an Early Famennian trunk from southeast Morocco. Am. J. Bot. 87, 456-468.

Meyer-Berthaud, B., Soria, A., Decombeix, A.L., 2010. The land plant cover in the Devonian: A reassessment of the evolution of the tree habit. Geol. Soc. Lond. Spec. Publ. 339, 5970.

Mintz, J.S., Driese, S.G., White, J.D., 2010. Environmental and ecological variability of Middle Devonian (Givetian) forests in Appalachian basin paleosols, New York, United States. Palaios 25, 85-86.

Momont, N., Gerrienne, P., Prestianni, C., 2016. Brabantophyton, a new genus with stenokolealean affinities from a Middle to earliest Upper Devonian locality from Belgium. Rev. Palaeobot. Palynol. 227, 77-96.

Morris, J.L, Leake, J.R., Stein, W.E., Berry, C.M., Marshall, J.E.A., Wellman, C.H., Milton, J.A., Hillier, S., Mannolini, F., Quirk, J., Beerling, D.J., 2015. Investigating Devonian trees as geo-engineers of past climates: linking palaeosols to palaeobotany and experimental geobiology. Palaeontology 58, 787-801.

Morris, J.L., Edwards, D., Richardson, J.B., 2018. The Advantages and Frustrations of a Plant Lagerstätte as Illustrated by a New Taxon From the Lower Devonian of the Welsh Borderland, UK. In: Krings, M., Harper, C., Cuneo, R., Rothwell, G.W. (Eds.), Transformative Paleobotany. Academic Press, pp. 49-67.

Niklas, K.J., Tiffney, B.H., Knoll, A.H., 1983. Patterns in vascular land plant diversification. Nature 303, 614-616. 
Niklas, K.J., Tiffney, B.H., Knoll, A.H., 1985. Patterns in vascular land plant diversification: analysis at the species level. In: Valentine, J.W. (Ed.), Phanerozoic Diversity Patterns: Profiles in Macroevolution. Princeton University Press, Princeton, pp. 97-128.

Orlova, O.A., Zavialova, N., Snigirevsky, S., Jurina, A. and Lidskaya, A., 2019. Kossoviella timanica Petrosjan emend. from the Upper Devonian of North Timan: morphology and spore ultrastructure. Earth Env. Sci. T. R. Soc. Edinb. 108, 335-372.

Prestianni, C., Gerrienne, P., 2010. Early seed plant radiation. An ecological hypothesis. In: Vecoli, L., Clément, G., Meyer-Berthaud, B. (Eds.), The Terrestrialization Process: Modelling Complex Interactions at the Biosphere-Geosphere Interface. Geol. Soc. Lond. Sp. Publ. 339, 71-80.

Prestianni, C., Gess, R.W., 2018. Rinistachya hilleri gen. et sp. nov. (Sphenophyllales), from the Upper Devonian of South Africa. Org. Divers. Evol. 19, 1-11.

Qie, W., Algeo, T.J., Luo, G., Herrmann, A., 2019. Global events of the late paleozoic (Early Devonian to Middle Permian): a review. Palaeogeogr. Palaeoclimatol. Palaeoecol. 531, 109259.

Raymond, A., Metz, C., 1995. Laurussian land-plant diversity during the Silurian and Devonian: mass extinction, sampling bias, or both? Paleobiology 21, 74-91.

Salamon, M.A., Gerrienne, P., Steemans,P., Gorzelak, P.,Filipiak, P., Le Hérissé,A., Paris, F., Cascales-Miñana, B., Brachaniec, T., Misz-Kennan, M., Niedziwiedzki, R., Trela, W., 2018. Putative Late Ordovician land plants from Poland. New Phytol. 218, 1305-1309.

Sallan, L.C., Coates, M.I., 2010. End-Devonian extinction and a bottleneck in the early evolution of modern jawed vertebrates. Proc. Natl. Acad. Sci. USA. 107, 10131-10135.

Sepkoski, J.J., 1981. A factor analytic description of the Phanerozoic marine fossil record. Paleobiology 7, 36-53.

Servais, T., Cascales-Miñana, B., Cleal, C.J., Gerrienne, P., Harper, D.A.T., Neumann, M., 2019. Revisiting the Great Ordovician Diversification of land plants: Recent data and perspectives. Palaeogeogr. Palaeoclimatol. Palaeoecol. 534, 109280.

Steemans, P., Petus, E., Breuer, P., Mauller-Mendlowicz, Gerrienne, P., 2012. Palaeozoic innovations in the micro- and megafossil plant record: from the earliest plant spores to the earliest seeds. In: Talent, J. (Ed.), Extinction Intervals and Biogeographic Perturbations Through Time. Springer, Berlin, 437-477.

Stein, W.E., Berry, C.M., Hernick, L.V., Mannolini, F., 2012. Surprisingly complex community discovered in the mid-Devonian fossil forest at Gilboa. Nature 483, 78-81. 
Stein, W.E., Mannolini, F., Hernick, L.V., Landing, E., Berry, C.M., 2007. Giant cladoxylopsid trees resolve the enigma of the Earth's earliest forest stumps at Gilboa. Nature 446, 904 907.

Stein, W.E., Berry, C.M., Morris, J.L., Hernick, L.V., Mannolini, F., Ver Straeten, C., Landing, E., Marshall, J.E.A., Wellman, C.H., Beerling, D.J., Leake, J.R., 2020. Mid-Devonian Archaeopteris Roots Signal Revolutionary Change in Earliest Fossil Forests. Curr. Biol. $30,421-431$.

Strullu-Derrien, C., Kenrick, P., Badel, E., Cochard, H., Tafforeau, P., 2013. An overview of the hydraulic systems in early land plants. IAWA J. 34, 333-351.

Thomas, B.A., Cleal, C.J., 2017. Distinguishing Pennsylvanian-age lowland, extra-basinal and upland vegetation. Palaeobiodiversity and Palaeoenvironments 97, 273-293.

Toledo, S., Bippus, A.C., Tomescu, A.M., 2018. Buried deep beyond the veil of extinction: Euphyllophyte relationships at the base of the spermatophyte clade. Am. J. Bot. 105, $1264-1285$.

Tomescu, A.M.F, 2009. Megaphylls, microphylls and the evolution of leaf development. Trends Plant Sci. 14, 5-12.

Wang, D.M., Liu, L., 2015. A new Late Devonian genus with seed plant affinities. BMC Evol. Biol. 15, 28.

Wang, D.M., Qin, M., Liu, L., Liu, L. Zhou, Y., Zhang, Y., Huang, P., Xue, J.Z., Zhang, S., Meng, M., 2019. The Most Extensive Devonian Fossil Forest with Small Lycopsid Trees Bearing the Earliest Stigmarian Roots. Curr. Biol. 29, 2604-2615.

Wellman, C.H., Steemans, P., Vecoli, M., 2013. Palaeophytogeography of Ordovician-Silurian land plants. In: Harper, D.A.T., Servais, T. (Eds.), Early Palaeozoic biogeography and palaeogeography. Geological Society Memoirs, London, 461-476.

Wilson, J.P., 2013. Modeling 400 million years of plant hydraulics. Paleont. Soc. Papers 19: $175-194$.

Wilson, J.P., 2016. Hydraulics of Psilophyton and evolutionary trends in plant water transport after terrestrialization. Rev. Palaeobot. Palynol. 227, 65-76.

Xiong, C., Wang, D.M., Wang, Q., Benton, M.J., Xue, J., Meng, M., Zhao, Q., Zhang, J., 2013. Diversity Dynamics of Silurian-Early Carboniferous Land Plants in South China. PLOS ONE 8, e75706.

Xue, J.Z., Huang, P., Ruta,M., Benton, M.J., Hao, S.G., Xiong, C.H., Wang, D.M., CascalesMiñana, B., Wang, Q., Liu, L., 2015. Stepwise evolution of Paleozoic tracheophytes from South China: contrasting leaf disparity and taxic diversity. Earth Sci. Rev. 148, 77-93. 
Xue, J.Z., Deng, Z.Z., Huang, P., Huang, K.J., Benton, M.J., Cui, Y., Wang, D.M., Liu, J.B., Shen, B., Basinger, J.F., Hao, S.G., 2016. Belowground rhizomes in paleosols: the hidden half of an Early Devonian vascular plant. Proc. Natl. Acad. Sci. USA. 113, 9451-9456.

Xue, J.Z., Huang, P., Wang, D.M., Xiong, C., Liu, L., Basinger, J.F., 2018. Silurian-Devonian terrestrial revolution in South China: Taxonomy, diversity, and character evolution of vascular plants in a paleogeographically isolated, low-latitude region. Earth-Sci. Rev. $180,92-125$

\section{Figures}

Fig. 1. Spindle diagrams showing the main diversity variations within plant classes (A) and the total shape of plant diversity (B) of the Silurian-Devonian time interval. Green colour highlights the total diversity pattern from well-established classes only (B). The width of each diagram indicates the number of fossil genera. The spindle diagrams undoubtedly can contain errors especially due to taxa with controversial affinities. Relative lengths of time units based on Cohen et al. (2013; updated). Abbreviations: W., Wenlock; L., Ludlow; Pri., Pridoli. *Note that Rhyniopsida includes herein current paratracheophytes and rhyniophytoids only.

Fig. 2. Scree graph showing eigenvalues from a Q-mode factor analysis of plant genera plotted logarithmically against their ranks. See Methods for details.

Fig. 3. Loadings of successive time intervals on rotated factors from a four-factor Q-mode analysis of plant genera plotted against absolute time. Factors represented in stratigraphical order. Relative lengths of used time units based on Cohen et al. (2013; updated). See Methods for details. Abbreviations: Wen., Wenlock; Lud., Ludlow; Pri., Pridoli; Pra., Pragian; Miss., Mississippian; C., Carboniferous.

Fig. 4. Representation of changing genus-level diversities within each of the evolutionary floras indicated by the four-factor model described in this paper. The highlighted uppermost curve shows the total pattern of the plant genus-level diversity through time. The stippled area immediately below represents the residual diversity not explained by the model. Relative lengths of time units based on Cohen et al. (2013; updated). See Methods for details. Abbreviations: Wen., Wenlock; Lud., Ludlow; Pri., Pridoli; Pra., Pragian; Miss., Mississippian; C., Carboniferous. 


\section{Tables}

Table 1. List of Silurian-Devonian plant groups considered in this study.

Table 2. Variance proportion explained by the first ten eigenvectors from a Q-mode factor analysis of the genus-level diversity of plant macrofossils from the mid-Silurian to the lowermost Carboniferous. See Methods for details.

Table 3. Scores of the main plant groups on the four rotated factors. The floral composition is given in four groups: scores $\geq 2$ (factors 1-2) or -2 (factors 3-4); scores $\geq 1$ (factors 1-2) or -1 (factors 3-4); scores $\geq 0.5$ (factors $1-2$ ) or -0.5 (factors $3-4$ ); scores $\geq 0.2$ (factors 1-2) or -0.2 (factors 3-4).

\section{Supplementary material}

Table S1. List of Silurian-Devonian plant genera considered in this study. For each genus, the plant group to which it belongs and/or its biological affinity, as well as its temporal distribution (first and last appearance) are provided. Compiled localities are justificative of exposed range only. See Text S1 for full references.

Table S2. List of lowermost Carboniferous (Tournaisian) plant genera considered in this study. For each genus, the plant group to which it belongs and/or its biological affinity, as well as its temporal distribution (first and last appearance) are provided. Compiled localities are justificative of exposed range only. See Text S1 for full references.

Text S1. Supplementary references. 


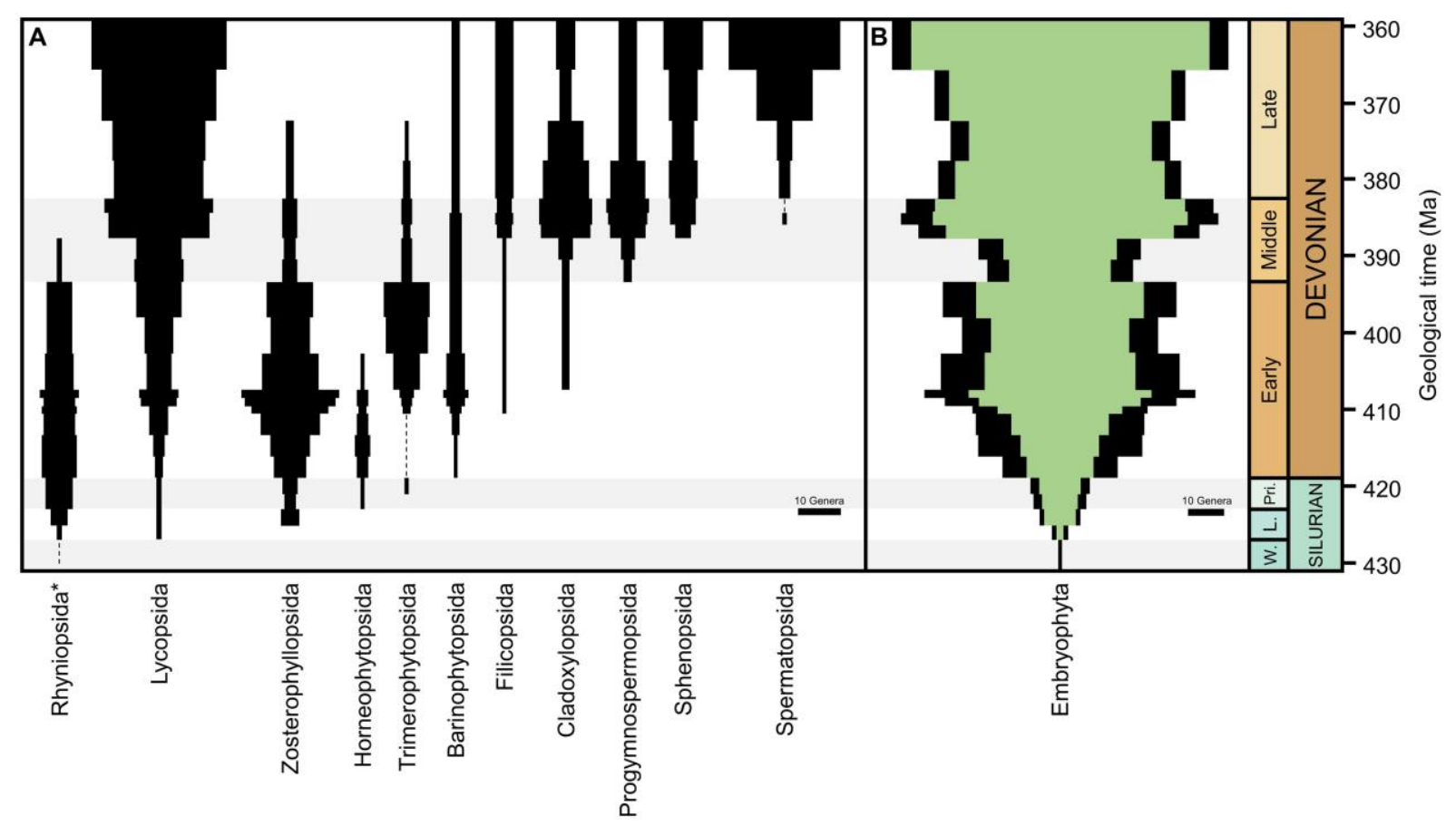

Figure 1

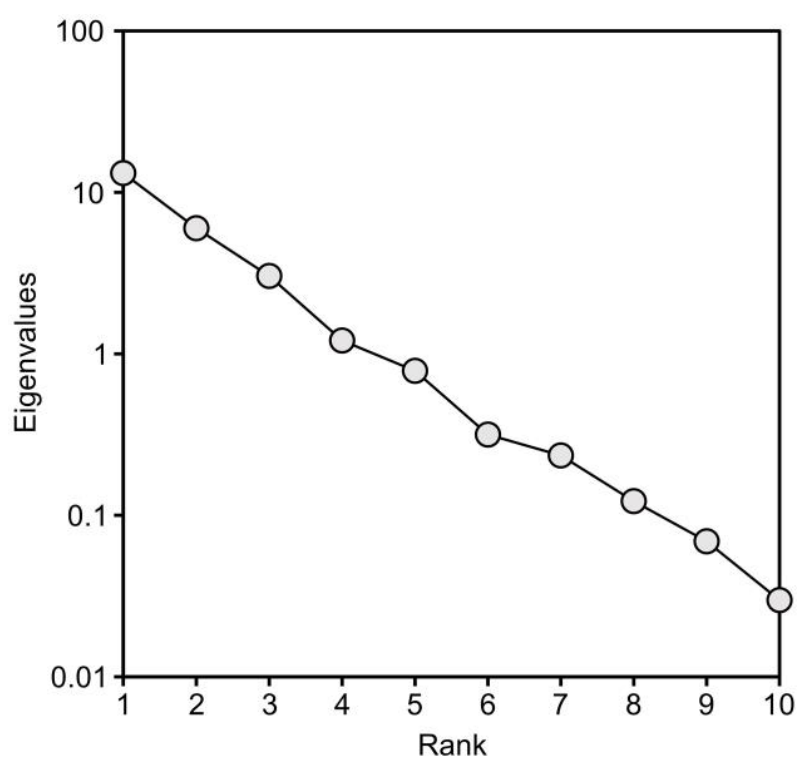

Figure 2 


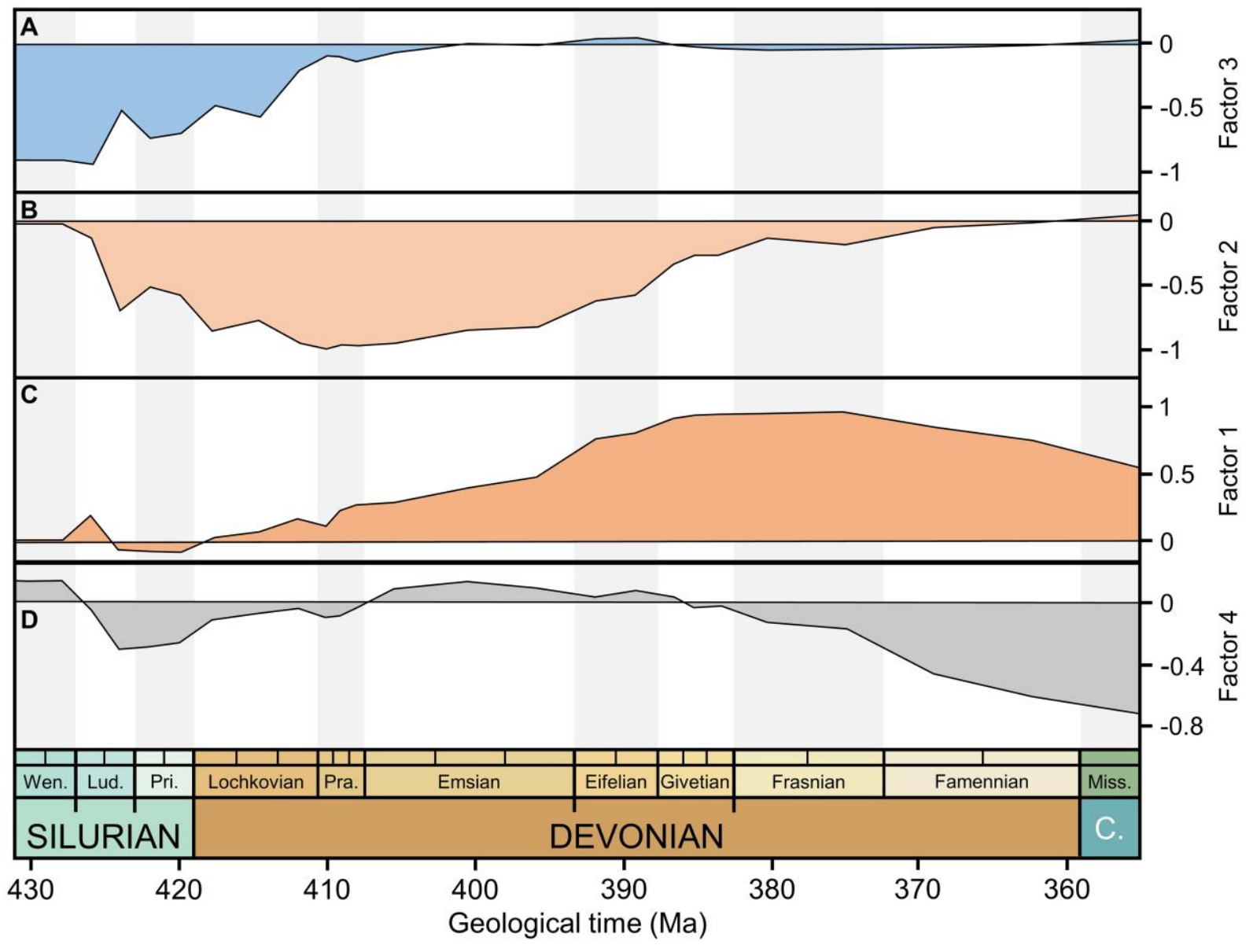

Figure 3 


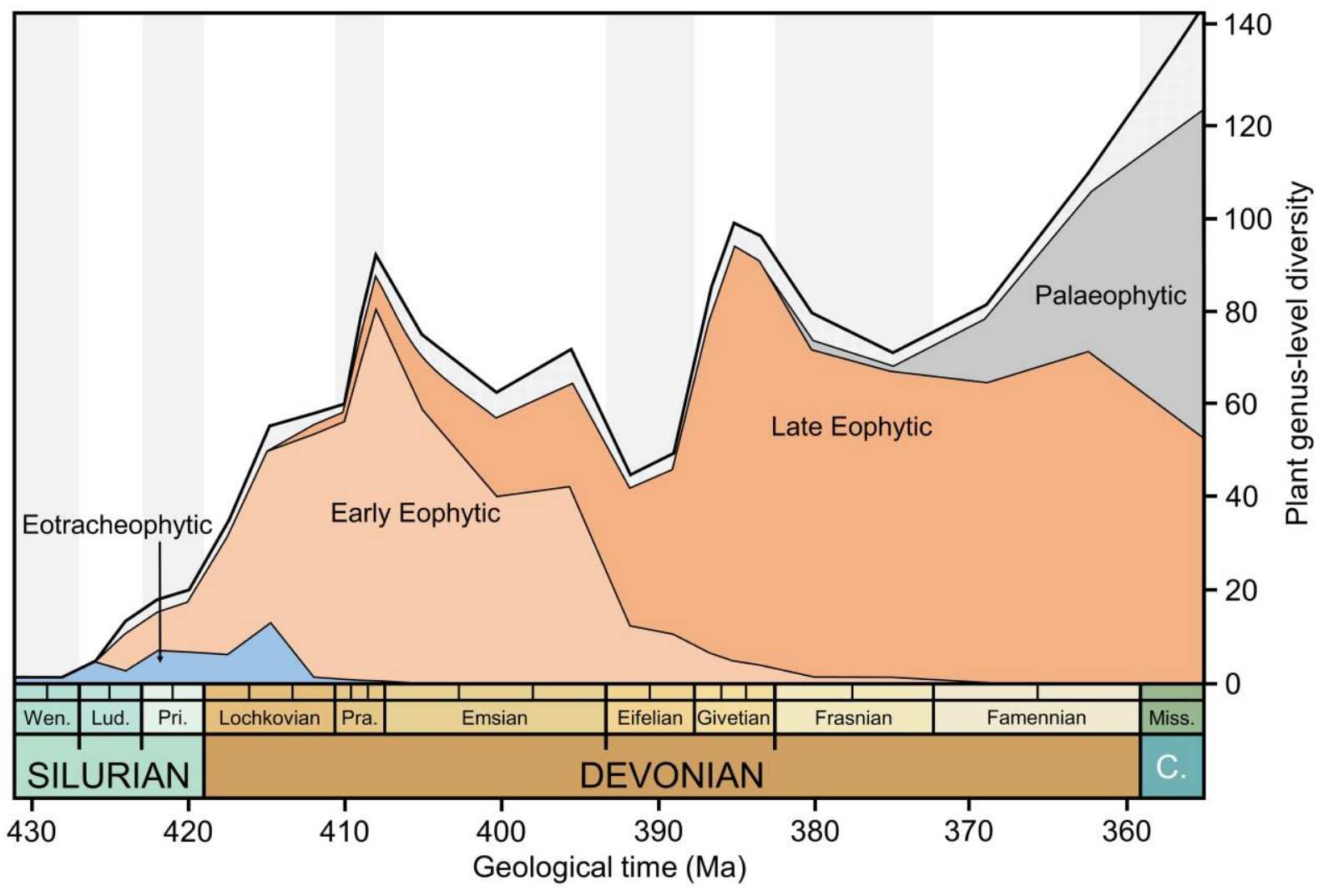

Figure 4 